This is an accepted manuscript of a book chapter by Marcin Kosienkowski, "The patronclient relationship between Russia and Transnistria," in De Facto States in Eurasia, ed. Tomáš Hoch and Vincenc Kopeček (Abingdon: Routledge, 2019), 183-207, DOI: $10.4324 / 9780429244049-14$

Marcin Kosienkowski, The John Paul II Catholic University of Lublin, Institute of Political Science and International Affairs

\title{
The patron-client relationship between Russia and Transnistria
}

\begin{abstract}
The chapter aims to analyze the patron-client relationship between Russia and Transnistria. More precisely, it investigates Russia's and Transnistria's rationale behind the establishment of their patron-client relations, the benefits derived by both parties from their relationship, and the efforts to legitimize their association. It then discusses the dynamics of the patron-client relationship between Russia and Transnistria. The chapter draws on previous theoretical and empirical research on relations between patrons and clients, covering both the Cold War and post-Cold War periods, as well as on secondary sources on Transnistria and statements made by the Russian and Transnistrian authorities.
\end{abstract}

Keywords: Russia, Transnistria, patron, client, de facto states, unrecognized states

\section{Introduction}

The patron-client concept originated in anthropological studies to describe inter-personal relations in small communities and then it has been transferred to higher levels, including the international level. The patron-client relationship in the international sphere can be defined as a mutually beneficial exchange of goods and services between two international actors, mainly states, that are unequal in terms of their military, economic, and political power. 
Benefits may be both tangible and intangible, for example, a patron (a stronger actor) may provide economic aid to a client (a weaker actor) in return for the latter's diplomatic support. Essentially, the resources exchanged are non-comparable; they are, however, valued by both parties. The international patron-client relationship has been studied more intensively, both theoretically and empirically, since the 1980s. The bulk of associated literature covers the Cold War era, focusing predominantly on patronage over client states from Africa, Asia, and Latin America by the two superpowers; the United States and Soviet Union (for example, Shoemaker and Spanier 1984; Carney 1989; Efrat and Bercovitch 1991). The patron-client relations between various states in the contemporary post-Cold war era have also been afforded some consideration (for example, Bar-Siman-Tov 1998, Ciorciari 2015, Veenendaal 2017).

While students of the patron-client relationship focus predominantly on relations between states, the international patron-client model has been extended to other types of international actors too. One example is collective patrons and clients consisting mainly of intergovernmental organizations and their member states (Ravenhill 1985). However, other actors are also included, such as "mini-states" that appeared at the beginning of the 1990s in Somalia when its central government collapsed; together they formed a collective client of the United Nations (Bariagaber 1996). Another example is Taiwan, acting as a patron of some microstates and, at the same time, as a client of the US (Veenendaal 2017). Due to a higher level of international recognition, it can be classified as an entity sui generis, placed between universally recognized states and de facto states that lack international recognition or enjoy it only at a minimal level. Finally, more recently, attempts have been made to employ the international patron-client concept to analyze relations between patron states and post-Soviet client de facto states, i.e. relations between Russia and Abkhazia, South Ossetia, and Transnistria as well as between Armenia and Nagorno-Karabakh (Devyatkov 2017; Berg and Vits 2018; Kolstø and Blakkisrud 2017).

This chapter aims to analyze, in a more systematic way, the patron-client relationship between Russia and Transnistria since the beginning of the twenty-first century. While Russia (initially the Soviet Union) has arguably exercised patronage over Transnistria since its proclamation in September 1990 (see map 9), their special relationship has become more palpable since around 2003. More precisely, this work investigates Russia's and Transnistria's rationale behind the establishment of their patron-client relations, the benefits derived by both parties from their relationship, and the efforts to legitimize their association. It then discusses the dynamics of the patron-client relationship between Russia and Transnistria. The chapter 
draws on previous theoretical and empirical research on relations between patrons and clients, covering both the Cold War and post-Cold War periods, as well as on secondary sources on Transnistria and statements made by the Russian and Transnistrian authorities.

\section{Russia's patronage: rationale, benefits, and legitimization}

\section{Rationale}

The main reason why stronger states establish and maintain patronal relations with weaker countries is that they seek to advance their national interests in this way (cf. Bariagaber 1996, 171-172). During the Cold War the two superpowers formed the patron-client relationship with African, Asian, and Latin American states because they expected to gain certain advantages over each other in their competition for influence over the world (Shoemaker and Spanier 1984, 11-14; Bercovitch 1991, 14-19). As pointed out by Kunihiko Imai and Peggy Ann James $(1996,166)$ not long after the end of the Cold War, "the major actors and their relative power may change, but their structural competition for influence over weaker states will remain a constant factor."

One such post-Cold War era rivalry is the competition between Russia and the West over the post-Soviet area. Moscow considers this region a sphere of its exclusive influence or a zone of its privileged interest and seeks to counterbalance the involvement of external actors (Kanet and Sussex 2015). Transnistria has a role to play in this struggle: as a Russian client, it affords Russia certain advantages over its Western adversaries in the competition for influence in two former Soviet republics: mainly in Moldova, Transnistria's parent state, but also in Ukraine, Transnistria's second neighbor (Dunn and Bobick 2014; Rogstad 2016; Kennedy 2016). Just as clients played a prominent role in the rivalry of their Cold War superpower patrons (Shoemaker and Spanier 1984, 13), so Transnistria plays a significant role in Russia's competition with the West, primarily over Moldova (Rodkiewicz 2012).

Russia's perception is that the competition over Moldova has intensified since late2003 and since then Russia has enhanced its special, patron-client relationship with Transnistria, making it more tangible for observers. In 2003 the Moldovan Communist authorities dismissed the Kozak Memorandum shortly before the signing ceremony under pressure from the United States, the European Union, the Organization for Security and Cooperation in Europe (OSCE), and a portion of Moldova's population. The Memorandum was 
a Russian-orchestrated plan for the settlement of the Transnistrian conflict, secretly negotiated with Moldova and Transnistria independently of other international actors. As pointed out by William H. Hill $(2012,7)$, the Head of the OSCE Mission to Moldova in 1991-2001 and 2003-2006, "what Western leaders in 2003 saw as a minor matter of blocking an unworkable political settlement in a small, remote post-Soviet divided state, Kremlin leaders saw as a direct geopolitical challenge and defeat on turf that had been theirs, relatively unchallenged, for [a long time] ... Moldova may have been one of the first places in the former USSR where Russia-United States and Russia-European Union relations moved from an uneasy, peripatetic cooperation to a more clearly adversarial posture."

Moreover, the Western actors stepped up their engagement in Moldova in the 2000s. This especially concerned the EU. Ahead of the 2004 Eastern enlargement, the EU decided to develop a comprehensive policy toward its southern and new Eastern neighbors in order to promote a ring of stability in the neighborhood, consisting of democratic and prosperous countries. This included Moldova - directly bordering the EU since 2007 when Romania had become a member, which was a potential source of security threats and a challenge for EU border integrity, being the poorest state in Europe with a hybrid political regime and a frozen conflict on its soil. Importantly, the idea of European integration has been in principle, promoted by the then and subsequent Moldovan governments, ultimately seeking EU membership (Całus and Kosienkowski 2018).

Since the launch of the European Neighborhood Policy in 2004, relations between the EU and Moldova, being greatly about the EU assisting Moldova in converging and integrating with the EU (but without offering membership), have been steadily deepening and strengthening (however, not without problems). This was demonstrated by the signing in June 2014 of an Association Agreement, including an agreement on a Deep and Comprehensive Free Trade Area (DCFTA). While Moldova has been advancing its European integration, the Kremlin wants Moldova to abandon this path and align with Russia. This includes participation in Russian integration projects in the post-Soviet area, falling under the umbrella of Eurasian integration. The latest project is the Eurasian Economic Union (EAEU), operational since 2015; previously it was the Eurasian Customs Union, launched in 2010 and was subsequently integrated into the EAEU (Całus and Kosienkowski 2018).

In the case of the competition between Russia and the West over Ukraine, it has intensified since late-2004. At this time the Western actors supported the Ukrainian Orange Revolution that called into question the initial victory in the presidential elections of the proRussian Viktor Yanukovych. This directly led to the election of Viktor Yushchenko, 
supporting Ukraine's EU and NATO memberships. The rivalry has further intensified as a result of the following Ukrainian revolution, called the Euromaidan Revolution, that took place at the turn of 2013 and 2014. Most Western governments sympathized with the protesters, while Russia backed the then President Yanukovych, who refused to sign the EUUkraine Association Agreement and then tried to violently crush the protests triggered by this decision. The revolution ended when the Euromaidan movement, explicitly pro-EU in its origins, ousted Yanukovych and a pro-Western government took power in Ukraine. Russia framed these events as a coup d'etat orchestrated by the US and responded with the annexation of Crimea and subversion in South and Eastern Ukraine. Subsequently, this led to a separatist war in Donbas and the emergence of the Donetsk and Luhansk People's Republics (Toal 2017).

\section{Benefits}

The two Cold War superpowers strove to obtain from their clients one or more of three specific types of benefits: ideological convergence, international solidarity, and strategic advantage, which is seen as the most important. These advantages were meant to increase the United States' and Soviet Union's power vis-à-vis each other in their global competition. The ideological benefits were gained when a client aligned to its patron ideology, at least in selected spheres. Moreover, such a client could be presented to the outside world as a showplace of the patron's ideological superiority in the hope of encouraging other states to converge upon it too. The benefits of international solidarity were about a client's voting cohesion with a patron in international organizations (mainly the $\mathrm{UN}$ ) or a client's pronouncements of support for a patron in international forums. Finally, the strategic benefits entailed gaining control over a client's strategically important territory and resources, including having a direct military presence. Furthermore, a client could be exploited by a patron as a surrogate in a regional conflict or a staging area for revolution (Shoemaker and Spanier 1984, 17-20; Carney 1989, 49-51).

As demonstrated by Eiki Berg and Kristel Vits $(2018,4)$ this typology can be applied to the post-Cold War relationship between patron states and client de facto states. Furthermore, it has also been employed to analyze post-Cold War relations between patrons and client microstates (Veenendaal 2017, 566-67) that share some similarities with de facto states, such as a small size, weak economies, and the need for external assistance (Comai 
2017). With regard to the Russian-Transnistrian patron-client relations, ideological convergence and benefits from international solidarity are of rather limited significance, while the most important benefit that Transnistria gives to Russia is a strategic advantage (cf. Berg and Vits 2018, 4; Devyatkov 2017).

The main example of an ideological benefit is when the Transnistrian authorities declared the de facto state's Eurasian integration "national idea" in November 2012 (MID PMR 2012). Importantly, in the same month the Russian authorities established an "NGO" called Eurasian Integration, based in Moscow and headed by the Russian MP, Aleksei Zhuravlyov, with the aim of constructing or renovating public buildings (e.g. hospitals and schools) in the Transnistrian region and providing it with public vehicles (e.g. ambulances and trolleybuses), using Russian governmental money (ANO "Yevraziiskaya Integratsiya” 2013). The idea was to make Transnistria a showplace of Eurasian integration's superiority and to sway the public opinion in Moldova that was not decisively in favor of European integration. What worked in favor of Russia's plan was the tangibility of the Russian support provided to Transnistria. In contrast the EU's assistance to Moldova was, in fact, barely visible to the Moldovan population, because it was mainly focused on institution building (Ghinea, Paul, and Chirila 2013, 2).

However, the Eurasian Integration organization virtually suspended its activity in 2018 because of a corruption scandal that left many Transnistrian subcontractors without payment (Tkhorik, Tuzlova, and Zvarish 2017). Moreover, being an unrecognized entity, Transnistria cannot, in reality, pursue Eurasian integration. Instead, it can integrate with the EU via Moldova and this is what has actually started to happen in the economic sphere. While the Transnistrian de facto state refused to co-negotiate and join the DCFTA agreement between the EU and Moldova, referring, among others, to its incompatibility with Eurasian integration, it finally decided in late-2015 to be included in the DCFTA (starting $1^{\text {st }}$ January, 2018) due to economic reasons and having won Russia's approval (Secrieru 2016; Całus 2016). Against this backdrop, Transnistria's declarations about Eurasian integration look more and more awkward.

Transnistria quite often displays solidarity with Russia. For instance, the Transnistrian authorities supported Russia's military invasion of Georgia and praised the subsequent recognition of Abkhazia and South Ossetia in August 2008 (MID PMR 2009). They also endorsed the annexation of the Crimea by Russia in March 2014 (MID PMR 2014). In all cases it was rather exceptional behavior, not only in the post-Soviet area, but also worldwide. Furthermore, the Transnistrian government harshly criticizes Moldovan attempts to get rid of 
Russian soldiers from Transnistria. An example is its criticism of the Moldova-sponsored resolution adopted by the UN General Assembly in June 2018, urging Russia to unconditionally withdraw Russian troops from the region (Krasnoselskii 2018c). However, given that, as an unrecognized entity, Transnistria is not a member of international organizations and has restricted access to international forums, these displays of solidarity yield rather little substantial benefit to Russia.

The main strategic advantage Transnistria gives to Russia is that the Transnistrian de facto state prevents Moldova from entering the EU. While in 2004 Cyprus joined the EU with the de facto state of Northern Cyprus on its territory, it is highly unlikely that the EU would be ready to repeat a similar scenario with regard to Moldova in the future. Furthermore, the breakaway region of Transnistria prevents Moldova from entering NATO, which has been Moldova's direct neighbor since 2007 when Romania became a member, is especially significant as the Transnistrian de facto state hosts Russian soldiers on its soil. To be sure, being a constitutionally neutral country, Moldova does not seek NATO membership, however, it cannot be ruled out that the Moldovan authorities will abandon neutrality some day in the future. This is a matter of great concern for Russia (Devyatkov 2014, 55).

Another strategic benefit is that Transnistria can be used by Russia to hinder the process of Moldovan integration into the EU, which has been underway since the beginning of the twenty-first century. Firstly, the mere existence of the Transnistrian de facto state provides the Kremlin with advantages. For example, the fact that the Moldovan central authorities do not control all of their territory has turned out to be a serious obstacle (eventually circumvented) to the conclusion of visa liberalization and DCFTA agreements between the EU and Moldova (Konończuk and Rodkiewicz 2012). Secondly, Russia can use the Transnistrian de facto state to trigger a crisis in relations between Transnistria and Moldova. The rationale is to convince the EU, including its member states, and Moldova to stop enhancing their cooperation in order to stabilize the region. ${ }^{1}$ One such Russian-inspired provocation may have been Transnistria's attempt to install checkpoints between a Moldovacontrolled village of Varnita, and a district of the Transnistria-controlled Bendery city in April 2013. As a result, a scuffle ensued between Transnistrian law enforcement officials and Moldovans, which could have turned into military hostilities (Całus 2013b). Thirdly, according to some experts (for example, Całus 2014), Transnistrian-based Russian and/or Transnistrian military units could have been used by the Kremlin to unfold a 2014

\footnotetext{
${ }^{1}$ Interview with a Western diplomat to Moldova, July 2013.
} 
Crimea/Donbas-like scenario in Moldova's pro-Russian regions such as Gagauzia. This would severely hamper the process of Moldova's European integration.

At the same time, Russia also uses Transnistria as a bargaining chip, alluding to the idea that the Transnistrian region could be reunited with Moldova if the Moldovan authorities aligned with Russia. What adds credibility to the Russian offer is that the Kremlin has never officially renounced its support for Moldova's territorial integrity and is the main, if not the only actor capable of pushing Transnistria, as its client, to abandon de facto independence (as demonstrated by Transnistria's approval of the Russia-orchestrated Kozak Memorandum in 2003). Crucially, in the case of reintegration under Russia's conditions the whole of Moldova could be anchored in Russia's sphere of exclusive influence. These provisions would legalize Russia's military presence in all of Moldova and guarantee a disproportionate degree of influence for pro-Russian Transnistria and Gagauzia in the united country, just as envisaged by the Kozak Memorandum (Hill 2012).

Another strategic advantage Transnistria gives to Russia is related to Ukraine. The Transnistrian de facto state is considered "an unsinkable aircraft carrier" on Ukraine's Western borders limiting the Ukrainian leadership's strategic options (Hensel 2006, 9). According to the Ukrainian authorities, Russia made attempts to use it directly, as a staging ground for Russian and Transnistrian subversive groups to infiltrate and destabilize the adjacent Ukrainian region of Odesa during the initial phase of Russian aggression against Ukraine in the winter and spring of 2014. Moreover, the Ukrainian government seemed to fear that the Transnistria-based Russian military units could invade Ukraine (see, for example, MZS Ukrayiny 2014; Ukrinform 2014; DPSU 2014). The aim of these actions would have been to establish another pro-Russian separatist republic within Ukraine to be included into the separatist, pro-Russian Novorossiya together with Transnistria and other Southern and Eastern Ukrainian regions, cutting Ukraine off from the Black Sea (Całus 2014; Goble 2014).

Even if the Russian authorities did not consider sending subversive groups to Ukraine or invading it from Transnistria, by posing such a threat, Russia tied up some Ukrainian military units close to the Transnistrian de facto state, preventing their deployment in the Donbas theatre of war. It can be added that Transnistria - as a pro-Russian region with Russian troops and security service - is still identified by the Ukrainian government as a direct threat to Ukraine's security and territorial integrity (Interfaks-Ukraina 2018). 


\section{Legitimization}

Stronger states point at derived benefits - that advance their interests - to justify upholding costly, patronal relations with weaker countries. In addition, they may refer to the affective factor stemming from ethnic, religious, ideological, historical or political affinities with clients (Carney 1989, 46, 51; Bercovitch 1991, 18; Ciorciari 2015, 248). In the case of its relationship with Transnistria, Russia avoids making any reference to its instrumental gains. The point is that the Kremlin would not like to be internationally associated with deriving benefits from a de facto state, considered by the international community to be an illegitimate entity. Instead, Russia legitimizes its patronage over Transnistria with affective and normative factors, i.e. its obligation to protect Russian citizens and compatriots, understood as people somehow identifying themselves with Russia or simply as members of the Russian world (Russkii Mir) living in the Transnistrian de facto state (Regnum 2009; Rossiiskaya Gazeta 2018). This is why Russian press releases on meetings between Transnistria's and Russia's representatives create the impression that mutual relations were restricted to socio-economic and humanitarian spheres as well as the Transnistrian conflict settlement process, being of great importance for ordinary Transnistrians (see, for example, MID RF 2016).

The number of Russia's citizens in the Transnistrian de facto state has been steadily growing (Nagashima 2017, 9-10). At present, 220 thousand Transnistrians hold Russian citizenship, which constitutes almost 50 percent of Transnistrian inhabitants. What is more, all of Transnistria's population - composed mainly of Russians, Moldovans, and Ukrainians appear to be considered compatriots by the Russian authorities. The Kremlin can support such a claim, for example, by referring to the 2006 Transnistrian referendum, in which virtually all Transnistrians backed the idea of Transnistria joining Russia.

\section{Transnistria's cliency: rationale, benefits, and legitimization}

\section{Rationale}

Weaker states become clients seeking to advance their national interests this way (cf. Gasiorowski and Baek 1987; Afoaku 2000; Constantin 1995, 185-186). For example, by entering the patron-client relationship, they may want to ensure their own survival. Christopher C. Shoemaker and John W. Spanier (1984, 21-22 and 183) noted that during the 
Cold War many states lived in what they perceived extremely hostile security environments, being afraid of military invasion by other states that would deal them a mortal blow. In such circumstances they looked for patrons for their salvation. Israel and Kuwait were cases in point. They looked for external protection against belligerent neighbors - i.e. respectively the Arab states and, mainly, Iraq - that put their very existence at risk (Sorokin 1997, 63-64; Tètreault 1991, 584-587). In the case of microstates in the post-Cold War period Wouter P. Veenendaal $(2017,567)$ points mainly at their economic vulnerability, resulting from having small, weak economies. In order to avoid economic collapse and survive they tend to associate themselves with stronger patrons. Quite similarly, in the face of famine "ministates" - that appeared in the territories of the failed Somalia at the beginning of 1990s decided to collectively enter a patron-client relationship with the UN, seeking the provision of food and other humanitarian aid necessary for their continued existence (Bariagaber 1996, 171).

De facto states share similar risks. They believe they are facing a constant military threat from their parent states that continue to lay claim to lost territories. They also have small, weak economies. Moreover, due to their non-recognition, de facto states are far more vulnerable - both military and economically - than the above-mentioned Cold War states and post-Cold War microstates (Kolstø 2006). While, in theory, they may enjoy the protection of the prohibition of the use of force (Coppieters 2018, 350 and 357), just as universally recognized states do, in practice, it does not hold true as demonstrated by the forcible eradications of the Republika Srpska Krajina in 1995, Chechnya in 1999, and Tamil Eelam in 2009. These events were met with virtually no international legal and non-legal consequences for, respectively, Croatia, Russia, and Sri Lanka. Furthermore, being unrecognized entities, de facto states are more or less economically isolated by the international community. This restricts their opportunities to obtain assistance from international financial institutions or bilateral donors, sell products abroad or attract foreign investment, making a de facto states' economic collapse and subsequent recapture by their parent state more likely.

As put by Berg and Vits $(2018,1)$ in reference to these vulnerabilities, de facto states face a "do or die" dilemma where they "either seek protection from external patrons ('do') or face the prospect of forceful reintegration back into their parent states ('die')." Transnistria has chosen the first option and associated itself with Russia since its outset at the beginning of the 1990s. To be sure, having failed to forcibly eradicate the Transnistrian de facto state in 1992, Moldova may not seek to retake its territories by force any longer, however, in the Transnistrian leadership's opinion such a threat has never disappeared. In addition, for some 
time during the Russian-Ukrainian conflict that erupted in 2014, the de facto state's authorities even seemed to believe that - as a pro-Russian entity - Transnistria could be invaded by Ukraine (Regnum 2015).

Furthermore, although when compared to the economies of other de facto states, Transnistria's highly industrialized economy is stronger and well-connected with the outside world in terms of trade (thanks to Moldova's consent). The Transnistrian de facto state is unable to function properly and simply survive by itself. The point is that Transnistria lacks enough internal resources - such as money to cover public expenses (including paying numerous public employees and pensioners) or the means of production (mainly natural gas), necessary for an economy based on heavy industry (Całus 2013a; Blakkisrud and Kolstø 2011, 188-193). For example, the de facto state will be able to cover only 36 percent of its budgetary expenditures in 2019 (Krudu 2018).

\section{Benefits}

According to Christopher P. Carney (1989, 48-49), by entering the patron-client relationship, the Cold War clients strove to derive security, economic, domestic, and diplomatic benefits that would help to advance their national interests (see also Gasiorowski and Baek 1987, 115; Bercovitch 1991, 17-18; Veenendaal 2017, 567; Ciorciari 2015, 252-257). With some additions this typology can be applied to the post-Cold War client de facto states that, struggling for their survival, associate themselves with stronger countries.

A client may obtain security guarantees as well as military equipment and training that enhance its position vis-à-vis its adversaries. A client country may also be provided with vital economic support by a patron, in the form of loans, grants, in-kind aid, and favorable trade conditions or investment. Furthermore, a patron's assistance that is used to improve material and physical wellbeing of the client's population can enhance the domestic legitimacy of a client government. While this also holds true in the case of de facto states, even more important is harnessing a patron's support to strengthen the domestic legitimacy of these entities. The point is that de facto states that have little popular support may not be able to mobilize armies or avoid massive emigration and may face collapse and reintegration by a parent state (Bakke et al. 2014, 591-594). Finally, a client may also receive diplomatic protection and backing in international forums or brokerage with the outside world. This is especially important in the case of more or less internationally isolated de facto states. 
With regard to Transnistria, it receives security guarantees from Russia, enhanced by the Russian military presence in the region. Russia keeps about 1,500 soldiers there within two formations - a peacekeeping contingent (within the trilateral Russian-MoldovanTransnistrian peacekeeping operation) and an Operational Group of Russian Forces (the OGRF is a remnant of the Soviet and then Russian Fourteenth Army). While Moldova and Western actors call for the transformation of the peacekeeping operation into a civilian one and for the withdrawal of the OGRF, this permanently meets with the Kremlin's refusal. Although Russia's military presence is limited, it nevertheless serves in the eyes of the Transnistrian authorities as a deterrent against Moldova's and, more recently, Ukraine's invasion of Transnistria that is highly unlikely anyway. Moreover, a potential attack would probably meet with a military response by Russia, even if it has no common border with Transnistria. Importantly, Russia's security guarantees allow the Transnistrian leadership to focus on state- and nation-building activities that strengthen Transnistria's de facto independence. It should be added that it was the Russian Fourteenth Army that secured Transnistria's victory in the 1992 war with Moldova as well as helped to create, equip and train Transnistrian armed forces (Blakkisrud and Kolstø 2011, 184-186; Lynch 2004, 74-79).

Undoubtedly, Transnistria gets vital economic support from Russia. Firstly, Russia provides the Transnistrian de facto state with natural gas, although Transnistria has only paid for some of it and since 2009, has not paid at all. This has led to its astronomical debt of more than $\$ 6$ billion (almost seven times more than Transnistria's GDP) owed to Gazprom at the end of 2017. The Russian gas is consumed predominantly by three large export-oriented industrial plants that are one of the main pillars of Transnistria's economy: Moldova Steel Works, the Moldavskaya GRES power plant, and the Rybnitsa Cement Plant. The next major gas consumer is Tirotex-energo - a power plant orientated to the needs of its owner, the Sheriff holding, that is another driving force of the Transnistrian economy. To be sure, the aforementioned and other corporate consumers pay Transnistria's authorities for the natural gas, however, it is bought at dumping prices, that reduces their production costs and makes their goods more competitive. This also means cheaper utilities, such as heating, improving the life of ordinary people. Furthermore, money collected from gas consumers - instead of being transferred to Gazprom - is used by the Transnistrian leadership to pay pensions and wages to public employees (Całus 2013a; Chamberlain-Creanga and Allin 2010, 336-339; Gorchakov 2016).

Secondly, Transnistria receives financial aid from Russia - on average \$100 million annually - in the form of loans and grants that are used to cover public expenses, increase 
pensions, assist Transnistrian businessmen and farmers, stabilize the Transnistrian currency and buy food for poor people. Thirdly, Russian companies are the main foreign investors in Transnistria, all the more important as the region is hardly attractive in terms of investment opportunities, due to its status of a de facto state. Fourthly, Transnistria receives Russian inkind support, via the aforementioned Eurasian Integration organization. Fifthly, Russia accepts economic migrants from Transnistria - their cash remittances are of great importance to the region's economy. Sixthly, Russia is one of the major markets for Transnistrian goods, however, its importance has declined over the course of time. Its share in Transnistria's exports accounted for 10.20 percent in January-August of 2018, placing it after Moldova (28.26 percent), Ukraine (21.81 percent), and Romania (17.03 percent) (Całus 2013a; Blakkisrud and Kolstø 2011, 188-193; GTK PMR 2018b).

As explained above, the Transnistrian population benefits economically - both directly (e.g. getting higher pensions or new public buildings) and indirectly (e.g. paying less for utilities) - from the patron-client relationship between Russia and Transnistria. Due to Russia's economic support for the de facto state, Transnistrians perceive the region's living conditions to be better than in Moldova, a country that Transnistria seeks to detach from (O’Loughlin, Toal, and Chamberlain-Creangă 2013, 235-240). Indeed, compared to its parent state, utilities are cheaper and pensions are higher in the Transnistrian de facto state (Karaban 2017). Thus, it can be said that benefits derived by Transnistria from Russia contribute to strengthening the de facto state's domestic legitimacy, even if the Transnistrian economy is actually marked by a permanent crisis and considerable workforce emigration.

To be sure, some may say that the fact that Transnistrians' wellbeing largely depends on Russia undermines the internal legitimacy of the Transnistrian de facto state (ChamberlainCreanga and Allin 2010, 339). This would be a problem, if Transnistria sought internationally recognized independence. However, since the 2006 referendum the Transnistrian de facto state has officially strived to join Russia. Moreover, the Transnistrian identity forged by Transnistria's authorities is based not only on a regional Transnistrian identity but also on a civilizational, Russian identity. As noted by Piotr Oleksy $(2016,143)$, “[b]eing a Transnistrian simply implies being a Russian (understood as a member of the Russian civilization) and at the same time does not interfere with being (in ethnic terms) a Bulgarian, a Ukrainian or a Moldovan."

Finally, Russia has also brought Transnistria under a protective umbrella in the international arena, such as the OSCE forum. In fact, it is the only country that provides the Transnistrian de facto state with diplomatic backing. For example, Russia praises Transnistria 
for progress within the Transnistrian conflict settlement process and points at Moldova as its main spoiler. Moldova is usually criticized for undertaking unilateral steps such as in May 2017, when they established a shared Moldovan-Ukrainian control post at the Transnistrian section of the Moldova-Ukraine border. The Russian point is that such actions are undertaken without consultations with the Transnistrian de facto state-that should be equal to Moldova - and undermine its de facto independence and performance. Furthermore, Russia's officials meet with Transnistrian officials, quite often addressing them with their official titles such as "the President of Transnistria" (see, for example, MID RF 2018; 2016). This enhances the legitimacy of Transnistria's officials and the legitimacy of the entity they represent.

While Transnistria's internal resources and its leadership's state- and nation-building efforts should not be underestimated (Kolstø 2006), in fact, the Transnistrian de facto state is able to survive only thanks to Russia's comprehensive assistance. This is generally accepted in the literature (see, for example, Popescu 2006) and has been overtly admitted by Transnistria's authorities (Gamova 2010; Sputnik 2016), even if they tend to underline that the Transnistrian de facto state is self-sufficient. This is also generally consistent with insights from literature on the patron-client relationship, saying that patrons play a crucial role in meeting their clients' demands (Bercovitch 1991, 15; Veenendaal 2017, 567).

To be sure, some may say that the Transnistrian de facto state depends on the West for survival as well, pointing out that a considerable part of Transnistria's exports go to the EU (Dembińska and Mérand 2018, 13; see also Berg and Vits 2018, 3), most recently, i.e. between January and August of 2018 this is 36.18 percent (GTK PMR 2018b). However, the vast majority of products exported to the EU - that is steel and textiles, constituting respectively 77.71 and 10.43 percent of Transnistria's European export (GTK PMR 2018a) were manufactured by companies (the Moldova Steel Works and the Sheriff-owned Tirotex) benefiting directly or indirectly (i.e. consuming electric energy generated using gas) from the natural gas provided by Russia to Transnistria for free. Others may say that Transnistria's survival depends also on Ukraine that provides the facto state with lines of communication and access to the international market, which is of crucial importance to its export-oriented economy (Istomin and Bolgova 2016, 182). However, it can be said it is largely due to Russia that this window to the outside world is permanently opened for Transnistria, even when Russian-Ukrainian relations are marked by hostility (cf. Istomin and Bolgova 2016, 185187). The point is that if Ukraine closed the border with Transnistria, it would create new tensions with Russia, which is something the Ukrainian authorities would rather like to avoid. 


\section{Legitimization}

The maintenance of the clientelist relationship means that weaker states expose themselves to the influence or control of stronger states (Carney 1989, 48). Because of these clients may be portrayed as "lackeys," "satellites" or "puppets" by third parties - this is what any government wants to avoid (Ciorciari 2015, 248). This is why client states deny abdicating autonomy to patrons and say that their relations with stronger countries are held on equal terms, branding these relations as a friendship or partnership. Clients also make an effort to legitimize upholding the relationship with patrons. Client de facto states are no exception to these patterns. This is especially true with respect to de facto states that strive for internationally recognized independence - the point is that the clientelist relationship reveals their non-viability and far-reaching dependencies on other states, making their claim to independent statehood less credible (Caspersen 2012, 108-109).

Clients usually point at derived benefits - that considerably advance their interests - to justify their association with stronger states. Furthermore, they may also refer to the affective factor, that bonds them to patrons, to legitimize their relationship. This affectivity stems from various similarities between parties (Ciorciari 2015, 252 and 267; Carney 1989, 44-46 and 51). These may be historical and linguistic affinities, like between African states and their former colonial masters such as France (Constantin 1995, 186), or normative commonalities, like between the two democracies - Israel and the US (Bar-Siman-Tov 1998, 232). The affectivity may also be based on a clients' feeling of gratitude toward patrons for assistance, such as in the case of the South Koreans' appreciation to the US for saving them from a possible Communist takeover and poverty in the 1950s (Kim and Lim 2007, 74; see also Veenendaal 2017). Finally, clients may point at common adversaries or threats shared with their patrons or, broadly speaking, converging interests of parties as well (Carney 1989, 51).

These patterns fit well with the relationship between Transnistria and Russia. The Transnistrian de facto state is quite often depicted in the media and scholarly works as no more than Russia's puppet (see, for example, Robertson 2014; Ivanel 2016). While Transnistria does not ultimately seek internationally recognized independence, it nevertheless attempts to improve this poor image. Transnistrian authorities underline their independency and brand Transnistria's relations with Russia as a partnership. They also try to legitimize this relationship by pointing to the Russian security guarantees and economic support to Transnistria that are crucial for its survival. The provision of such vital assistance generates positive feelings toward Russia - which is called Transnistria's savior and "hope for the 
future" - and additionally used to justify the Transnistrian de facto state's clientelist relationship with its patron (Smirnov 2007; Krasnoselskii 2018b).

The Transnistrian leadership also refers to other affective factors, stemming from historical and cultural commonalities. Indeed, the Transnistrian region has been almost persistently connected with Russia - understood not only as contemporary Russia but also the Tsarist Russia and the Soviet Union - since the end of the eighteenth century, when it was merged with the Russian Empire. Apart from this historical affinity, the Transnistrian de facto

state's population is heavily Russified and has a deep sense of togetherness with Russia, despite the fact that Transnistria is a multi-ethnic region. This is why Transnistria is presented by its leadership as an integral part of the Russian civilization (the Russkii Mir) and even as a mirror reflection of Russia inhabited by model Russians. Furthermore, the Transnistrian authorities claim that Transnistria's and Russia's interests largely converge. For example, they point out that both parties want Russian soldiers to be stationed in the Transnistrian territory. Last but not least, the special relationship with Russia is justified by its consistency with Transnistria's officially declared goals - based on the people's will - of Eurasian integration and ultimate accession to Russia (Smirnov 2007; Krasnoselskii 2018b).

\section{Dynamics of the patron-client relationship between Russia and Transnistria}

\section{Mutually valued relationship marked by tensions}

The patron-client relationship is based on the premise that the supply of goods and services by one party to another meets with the reciprocal provision of (non-comparable) resources. In other words, both a patron and a client give and take. This instrumental, mutually valued exchange of resources sustains patron-client relations. The relationship may be further enhanced by the affective factor, originating from similarities between parties or a client's gratitude towards a patron for assistance. However, as pointed by Jacob Bercovitch (1991, 19), "[b]ehind the formal façade of loyalty, shared interests ... there is an informal reality of tensions, disagreements and shifting directions of influence" in patron-client relations. The main problem is that parties try to extract as much support as possible from each other, while seeking to minimize their own concessions. Moreover, being perceived as too costly or risky, some demands may be hard to meet. There may be also red lines not to be crossed 
(Shoemaker and Spanier 1984, 17, 24; Bercovitch 1991, 18-19; Bariagaber 1996, 166; Heimann 2010; Ciorciari 2015, 248; Ladwig 2016, 105).

Likewise, the patron-client relationship between Russia and Transnistria is generally mutually beneficial and valued as well as marked by a strong element of affectivity based on affinities and Transnistria's appreciation of Russian assistance, however, it is not free from serious tensions. First of all, the Russian and Transnistrian authorities totally differ on such a crucial issue as the future status of Transnistria. Unlike the Transnistrian government, the Russian authorities want Transnistria to be reintegrated with Moldova (under Russian conditions that would anchor Moldova in Russia's sphere of exclusive influence). Instead, referring to the results of the 2006 referendum, the Transnistrian leadership seeks its de facto state to be incorporated into Russia, this is something the Russian authorities do not want to do (cf. Kosienkowski 2012, 16-29).

Furthermore, the Transnistrian government desires Russian financial assistance to keep flowing to the region, whereas the Kremlin tends to limit such support because of political or economic reasons. There were even cases when the financial aid was halted - as seen for the entirety of 2007 and 2017 - substantially worsening the socioeconomic situation in the Transnistrian de facto state. It can also be noted that while Russia may have considered using the Russian army based in the Transnistrian region to invade Ukraine, this seemed to contradict the interests of Transnistria because it may have put the Transnistrian de facto state's performance and existence at risk (Oleksy 2014; Novosti Pridnestrovya 2014).

\section{Achieving Transnistria's compliance}

Normally patrons achieve a clients' compliance with their needs through inducement, i.e. providing and increasing support to clients. The more a given client values gained benefits, the more it is responsive to a patron's demands. De facto states can be classified as clients that highly regard a patron's assistance, given that it ensures their survival. Moreover, this support is hard to replace. The point is that, due to the illegitimate status of de facto states, the number of their potential patrons is extremely limited, if not non-existent (Kolstø and Blakkisrud 2017, 506). As such, de facto states can be expected to be highly responsive to the demands of their patrons.

In the case of problems, clients can simply be reprimanded by patrons to ensure their voluntary compliance. Moreover, their behavior can also be shaped through the threat or use 
of coercion. This can be about the reduction of economic aid, trade restrictions or increased diplomatic pressure (Carney 1989, 47-48; Bercovitch 1991, 15-19 and 27; Bariagaber 1996, 172-174; Ladwig 2016, 105-108). Furthermore, while patrons appreciate a client states' internal stability (Afoaku 2000), they may nevertheless try to influence domestic politics in client countries in order to replace their governments with more compliant authorities (Gasiorowski and Baek 1987).

As regards to the Russian-Transnistrian relationship, the vital and non-replaceable support provided by Russia to Transnistria makes the Transnistrian de facto state's leadership highly responsive to demands from the Russian authorities and even anticipatory to their needs. ${ }^{2}$ Yet, sometimes the Transnistrian government has had to be reprimanded by Russia, just as in the case of Yevgenii Shevchuk who served as the second president of Transnistria between 2011 and 2016. Having come to power he pursued his own, pragmatic foreign policy for a few months but, admonished by the Kremlin, he voluntarily and smoothly started complying with Russia's needs (Całus and Oleksy 2013; see also Kosienkowski 2012). According to some accounts, he became even "more Russian than Russia."”

There were also cases when the Transnistrian leadership did not want to follow its patron's will - this especially concerned the first Transnistrian president, Igor Smirnov, who held his position between 1991 and 2011. As a result, the Russian authorities resorted to threats or the use of coercion. More precisely, they restricted or halted financial support (or made threats to do it), demanded the gas debt to be paid back, threatened to cut off gas deliveries, and exerted diplomatic pressure on Transnistria. As a result, the Transnistrian leadership had no choice but to comply. Russia employed such tactics primarily when the opportunity appeared - i.e. when the Moldovan authorities were ready to align with Russian interests - to make Transnistria reintegrate with its parent state or simply negotiate with Moldova on the conflict settlement. Russia's successful attempt to make Transnistria approve the Kozak Memorandum - a Russian-orchestrated plan of the Transnistrian conflict settlement - is a case in point (Soloviev 2007, 2008; Hill 2012, 124, 138, 175). It can also be added that Russia restricted the provision of funds to Transnistria seeking to save money (Całus 2017) or because of money misappropriation by the Transnistrian authorities (Soloviev 2007; Soloviev and Butrin 2010).

Being afraid that internal instability in Transnistria could undermine the de facto state's existence, Russia supports subsequent Transnistrian authorities, supervises the peaceful

\footnotetext{
${ }^{2}$ Interviews with former senior officials in the Transnistrian Foreign Ministry, July 2013.

${ }^{3}$ Interviews with former senior officials in the Transnistrian Foreign Ministry, July 2013.
} 
transfer of power after elections, and helps to reconcile contending Transnistrian political groups (Devyatkov and Kosienkowski 2013, 314-316; Kolstø and Blakkisrud 2017, 519526). However, the 2011 presidential election in Transnistria is an exception to this rule. Being dissatisfied with the then President Smirnov's non-compliance with Russia's needs and misappropriation of Russian financial aid, the Kremlin started to put pressure on Smirnov not to run for his fifth term as president. This included spreading slanderous material about Smirnov by the Russian media, which was very popular in Transnistria, and initiating a criminal case by the Russian Investigation Committee against his son, accused of embezzling money, including Russian humanitarian assistance granted to the Transnistrian de facto state. Largely due to Russia's campaign, Smirnov was expelled from the presidential run after the first round of the elections. Yet, it should be added that the Kremlin did not manage to ensure the victory of its candidate, Anatolii Kaminskii; instead, it was Yevgenii Shevchuk who won the election (Devyatkov and Kosienkowski 2013, 315-317).

\section{Achieving Russia's compliance}

Patrons comply with clientelist demands in reciprocation for the benefits provided to them by their clients. At the same time, clients can undertake additional steps to maintain (in case of problems) or achieve a higher degree of a patrons' compliance with their preferences and retain more autonomy vis-à-vis stronger states. First of all, clients can influence a patrons' behavior by threatening to abandon them and become clients of other states or play two (or more) patrons off against each other (Bercovitch 1991, 16; Afoaku 2000, 17; Veenendaal 2017, 567). To be sure, de facto states have limited opportunities to employ these tactics, given that there are no alternative patrons in sight. However, it does not mean that such tactics cannot be used in some form.

Clients can also rely on lobbying patronal governments by friendly officials, politicians, and activists from patron states (Afoaku 2000; Bercovitch 1991, 23-24). Additionally, client countries can (over)emphasize the importance of benefits they provide (or may provide) to their patrons (Bar-Siman-Tov 1998, 244; Afoaku 2000, 18; Jourde 2007) and anticipate patronal interests, trying to satisfy them and obtain sympathy and the benevolence of patrons (Veenendaal 2017, 572). Finally, clients can make emotional appeals to a patrons' government and public opinion referring to various affinities between clients and patrons (Bercovitch 1991, 24). 
The Transnistrian authorities take similar steps in order to maintain or achieve a higher degree of Russia's compliance with Transnistria's needs and the ability to retain more autonomy vis-à-vis the Russian patron. While there is no country ready to replace Russian patronage and provide Transnistria with security guarantees as well as vital economic assistance, the Transnistrian authorities pretended to seek an alternative patron exactly as the de facto state lost Russia's support. The aim of such tactics was to pressure the Kremlin to resume aid. During the Smirnov presidency, Transnistria announced its intention to enhance cooperation with Ukraine, including possibly joining this state. Moreover, the Transnistrian de facto state even expressed the intention to conduct multi-vector foreign policy or closely cooperate with the EU and the US, instead of Russia (Kosienkowski 2012, 19 and 27; Istomin and Bolgova 2016). While due to the Russian-Ukrainian conflict Transnistria cannot court Ukraine any longer, the Transnistrian leadership can still exploit (trade) links with the EU, trying to influence Russia. Perhaps, this is why-having not received the Russian financial support for the whole of 2017 - the Transnistrian President, Vadim Krasnoselskii (2018a), said that Transnistria should become a place where the (competing) interests of the European Union (and generally the West) and Russia could be reconciled.

Furthermore, the Transnistrian authorities rely on Russian officials and politicians of various levels as well as military officers, willing to lobby the Russian authorities for the Transnistrian cause. These are nationalists, communists or opportunists as well as people coming from the Transnistrian region or elected by Russian citizens living in Transnistria. These are also Russian businessmen that - encouraged by the Transnistria's authorities invested their money in the Transnistrian de facto state (Kosienkowski 2012, 26; Hill 2012, 70). Furthermore, the Transnistrian leadership emphasizes the region's geostrategic importance to Russia, presenting it as the last Russian military stronghold in Southeastern Europe. For example, the Smirnov regime made an effort to underline this, suggesting the deployment of the medium-range Iskander missiles in Transnistria in 2010, in response to Romania's intentions to have elements of a US anti-missile shield on its territory (Kosienkowski 2012, 26-27).

The Transnistrian authorities also claim that Russia should protect and endorse its citizens and compatriots living in Transnistria, calling it an outpost of the Russian civilization in this part of Europe. Additionally, when the de facto state lost Russia's assistance, the Smirnov regime resorted to histrionics and appealed to Russian public opinion and nationalist politicians for support (Kosienkowski 2012, 24-27; Oleksy 2016, 167-174). Overall, it can be said that all these steps help shape Russia's policy toward Transnistria in the direction desired 
by the Transnistrian authorities, especially during periods when the Russian government does not see the opportunity of merging Transnistria with Moldova. Referring to the period of the Smirnov regime, a senior expert of the Carnegie Moscow Center even called it a case of the tail wagging the dog. ${ }^{4}$

\section{Conclusions}

As demonstrated in this chapter, the relations between Russia and the de facto state of Transnistria can be analyzed by employing the patron-client concept. Such a relationship between the stronger Russian patron and the weaker Transnistrian client is essentially about the mutually beneficial exchange of non-comparable goods and services. The most important benefit that Russia derives from Transnistria is a strategic advantage. It allows Russia to increase its power in the competition with Western actors for influence in two of the former Soviet republics: mainly in Moldova, Transnistria's parent state, but also in the Ukraine. While legitimizing its special relationship with Transnistria, however, Russia refers exclusively to affective and normative arguments, that it is its obligation to protect Russian citizens and compatriots living in the Transnistrian region. The reason is that it does not want to be associated with the instrumental use of a de facto state that is considered an illegitimate entity by the international community.

In return, Transnistria obtains security, economic, domestic, and diplomatic benefits from Russia. Among others, the Transnistrian de facto state is provided with guarantees of security, free natural gas, financial aid, and diplomatic protection in international forums. The economic assistance also reaches the population, strengthening Transnistria's domestic legitimacy. Crucially, the support derived from Russia is necessary for Transnistria to survive as a de facto state. Being often depicted as no more than a Russian puppet, Transnistria attempts to legitimize its clientelist relationship with Russia. It refers to the importance of instrumental benefits as well as affective factors, such as historical and cultural commonalities with the Russian patron, and converging interests of both parties.

This instrumental, mutually beneficial exchange of goods and services is what sustains relations between Russia and Transnistria. They are further enhanced by a strong element of affectivity based mainly on affinities between parties. However, the relationship is not free from serious tensions. The fundamental divergence is that the Russian authorities want

\footnotetext{
${ }^{4}$ Interview, November 2007.
} 
Transnistria to be reintegrated with its parent state under Russian conditions that would anchor Moldova in Russia's sphere of exclusive influence. Alternatively, the Transnistrian leadership wants Transnistria to be integrated with Russia. Facing such problems, parties undertake additional steps to achieve each other's compliance with their needs. These include Russia resorting to coercion and Transnistria lobbying the Russian government via individuals sympathizing with the Transnistrian cause. While Transnistria is neither a Russian puppet nor a powerless actor vis-à-vis its Russian patron, however, if resolutely pressed by Russia, it has no choice but to finally comply with its patron's demands. What is decisive is that Russia provides Transnistria with vital and non-replaceable support.

\section{Literature}

Afoaku, Osita G. 2000. "U.S. foreign policy and authoritarian regimes: Change and continuity in international clientelism." Journal of Third World Studies 17 (2): 13-40.

ANO Yevraziiskaya Integratsiya. 2013. "O nas [About us].” ANO Yevraziiskaya Integratsiya [Autonomous Non-Commercial Organization Eurasian Integration], May 29 http://eurasianintegration.ru/?q=node/71.

Bakke, Kristin M., John O’Loughlin, Gerard Toal, and Michael D. Ward. 2014. "Convincing State-Builders? Disaggregating Internal Legitimacy in Abkhazia." International Studies Quarterly 58 (3): 591-607.

Bariagaber, Assefaw. 1996. "The United Nations and Somalia: An Examination of a Collective Clientelist Relationship." Journal of African and Asian Studies 31 (3-4): 162177.

Bar-Siman-Tov, Yaacov. 1998. "The United States and Israel since 1948: A 'Special Relationship'?” Diplomatic History 22 (2): 231-262.

Bercovitch, Jacob. 1991. "Superpowers and client states: Analysing relations and patterns of influence." In Superpowers and Client States in the Middle East: The imbalance of influence, edited by Moshe Efrat and Jacob Bercovitch, 9-32. London and New York: Routledge.

Berg, Eiki, and Kristel Vits. 2018. "The Do-or-Die Dilemma Facing Post-Soviet De Facto States.” PONARS Eurasia Policy Memo 527. http://www.ponarseurasia.org/sites/default/files/policy-memos-pdf/Pepm527_BergVits_May2018.pdf.

Blakkisrud, Helge, and Pål Kolstø. 2011. "From Secessionist Conflict Toward a Functioning State: Processes of State- and Nation-Building in Transnistria." Post-Soviet Affairs 27 (2): $178-210$. 
Całus, Kamil. 2013a. "An aided economy: The characteristics of the Transnistrian economic model." OSW Commentary, May 14.

https://www.osw.waw.pl/sites/default/files/commentary_108.pdf.

Całus, Kamil. 2013b. "Tensions between Moldova and Transnistria pose a threat to the Vilnius summit." OSW Analyses, July 10.

https://www.osw.waw.pl/en/publikacje/analyses/2013-07-10/tensions-between-moldovaand-transnistria-pose-a-threat-to-vilnius.

Całus, Kamil. 2014. “Crimean Gagauzia?” New Eastern Europe, March 13. http://neweasterneurope.eu/2014/03/13/crimean-gagauzia/.

Całus, Kamil. 2016. "The DCFTA in Transnistria: Who gains?" New Eastern Europe, January 15. http://neweasterneurope.eu/old_site/articles-and-commentary/1861-the-dcfta-intransnistria-who-gains.

Całus, Kamil. 2017. “The Transnistrian gambit.” New Eastern Europe, December 21. http://neweasterneurope.eu/2017/12/21/the-transnistrian-gambit/.

Całus, Kamil, and Marcin Kosienkowski. 2018. "Relations between Moldova and the European Union." In The European Union and its eastern neighbourhood: Europeanisation and its twenty-first-century contradictions, edited by Michael Mannin and Paul Flenley, 99-113. Manchester: Manchester University Press.

Całus, Kamil, and Piotr Oleksy. 2013. "Expectations and Reality Collide in Tiraspol." New Eastern Europe, June 9. http://neweasterneurope.eu/2013/06/09/expectations-and-realitycollide-in-tiraspol/.

Carney, Christopher P. 1989. "International Patron-Client Relationships: A Conceptual Framework." Studies in Comparative International Development 24 (2): 42-55.

Caspersen, Nina. 2012. Unrecognized States: The Struggle for Sovereignty in the Modern International System. Cambridge: Polity.

Chamberlain-Creanga, Rebecca, and Lyndon K. Allin. 2010. “Acquiring Assets, Debts and Citizens: Russia and the Micro-Foundations of Transnistria's Stalemated Conflict." Demokratizatsiya 18 (4): 329-356.

Ciorciari, John D. 2015. "A Chinese model for patron-client relations? The Sino-Cambodian partnership.” International Relations of the Asia-Pacific 15 (2): 245-278.

Comai, Giorgio. 2017. "Conceptualising Post-Soviet de facto States as Small Dependent Jurisdictions." Ethnopolitics 17 (2): 181-200.

Constantin, François G. 1995. "The Foreign Policy of Francophone Africa: Clientelism and After." In State and Society in Francophone Africa since Independence, edited by Anthony Kirk-Greene and Daniel Bach, 183-199. Basingstoke: St. Martin's Press. 
Coppieters, Bruno. 2018. “'Statehood', 'de facto Authorities' and 'Occupation': Contested Concepts and the EU's Engagement in its European Neighbourhood.” Ethnopolitics 17 (4): 343-361.

Dembińska, Magdalena, and Frédéric Mérand. 2018. "The role of international brokers in frozen conflicts: The case of Transnistria.” Asia Europe Journal, 1-16.

Devyatkov, Andrey. 2014. "Russian Policy Toward Transnistria: Between Multilateralism and Marginalization.” Problems of Post-Communism 59 (3): 53-62.

Devyatkov, Andrey. 2017. "Russia and Transnistria in a patron-client relationship." Laboratorul pentru Analiza Conflictului Transnistrean, April 17. http://www.lact.ro/2017/04/17/andrey-devyatkov-russia-and-transnistria-in-a-patron-clientrelationship/.

Devyatkov, Andrey, and Marcin Kosienkowski. 2013. "Testing Pluralism: Transnistria in the Light of 2011 Presidential Elections." In Spotkania polsko-mołdawskie: Księga poświęcona pamięci Profesora Janusza Solaka [Polish-Moldovan Encounters: The Commemorative Book for Professor Janusz Solak], edited by Marcin Kosienkowski, 303-328. Lublin: Episteme.

DPSU. 2014. "Derzhprykordonsluzhba zdiisnyuye posylenu okhoronu derzhavnoho kordonu [The State Border Service carries out the enhanced protection of the state border]." Derzhavna prykordonna sluzhba Ukrayiny, March 21. https://dpsu.gov.ua/ua/news/derzhprikordonslyzhba-zdijsnjuje-posileny-ohoronyderzhavnogo-kordony/.

Dunn, Elizabeth Cullen, and Michael S. Bobick. 2014. "The empire strikes back: War without war and occupation without occupation in the Russian sphere of influence." American Ethnologist 41 (3): 405-413.

Efrat, Moshe, and Jacob Bercovitch, eds. 1991. Superpowers and Client States in the Middle East: The imbalance of influence. London and New York: Routledge.

Gamova, Svetlana. 2010. "Amerikanskaya PRO kak podarok Pridnestrovyu [American AntiMissile Defence as a present for Transnistria]." Nezavisimaya Gazeta, March 3. http://www.ng.ru/cis/2010-03-03/1_pro.html.

Gasiorowski, Mark J., and Seung-hyun Baek. 1987. "International Cliency Relationships and Client States in East Asia.” Pacific Focus 2 (2): 113-143.

Ghinea, Cristian, Amanda Paul, and Victor Chirila. 2013. "Helping Moldova stay on the EU course: Proposals for a real 'more for more' approach." EPC Policy Brief, December 11. http://www.epc.eu/documents/uploads/pub_4006_helping_moldova_stay_on_the_eu_cours e.pdf.

Goble, Paul. 2014. "Moscow Threatens Ukraine from the West." Eurasia Daily Monitor, March 25. https://jamestown.org/program/moscow-threatens-ukraine-from-the-west/. 
Gorchakov, Sergey. 2016. "Mify o pridnestrovskom postavshchike rossiiskogo gaza [Myths about Russian gas supplies to Moldova]." Novosti Pridnestrovya, October 6.

https://novostipmr.com/ru/news/16-10-06/mify-o-pridnestrovskom-postavshchikerossiyskogo-gaza.

GTK PMR. 2018a. "Vneshnyaya torgovlya PMR po osnovnym stranam i gruppam stran v razreze tovarnykh struktur za yanvar-avgust $2018 \mathrm{~g}$. [International trade of the TMR major trade partners, groups of countries and commodities, January-August 2018]." Gosudarstvennyi Tamozhennyi Komitet Pridnestrovskoi Moldavskoi Respubliki, September 14. http://customs.gospmr.org/vneshnyaya-torgovlya-pmr-po-osnovnymstra.html.

GTK PMR. 2018b. "Vneshnyaya torgovlya PMR po osnovnym stranam i gruppam stran za yanvar-avgust $2018 \mathrm{~g}$. [International trade of the TMR - major trade partners, groups of countries, January-August 2018]." Gosudarstvennyi Tamozhennyi Komitet Pridnestrovskoi Moldavskoi Respubliki, September 14. http://customs.gospmr.org/2014-3.html.

Heimann, Gadi. 2010. "From Friendship to Patronage: France-Israel Relations, 1958-1967." Diplomacy \& Statecraft 21 (2): 240-258.

Hensel, Stuart. 2006. Moldova Strategic Conflict Assessment (SCA). London: UK Global Conflict Prevention Pool.

Hill, William H. 2012. Russia, the Near Abroad, and the West: Lessons from the MoldovaTransdniestria Conflict. Washington, DC: Woodrow Wilson Center Press.

Imai, Kunihiko, and Peggy Ann James. 1996. "Dynamics of a Trilateral Game of Influence: Interactions between Major Powers' Foreign Policy Instruments and the Behavior of Weaker States." International Interactions 22 (2): 165-195.

Interfaks-Ukrayina. 2018. "Poroshenko zayavlyaet o roste boegotovnosti VSU [Poroshenko on increase in combat readiness of the Armed Forces of Ukraine]." Interfaks-Ukryina, October 11. https://interfax.com.ua/news/general/537359.html.

Istomin, Igor, and Irina Bolgova. 2016. "Transnistrian strategy in the context of RussianUkrainian relations: The rise and failure of 'dual alignment'." Southeast European and Black Sea Studies 16 (1): 169-194.

Ivanel, Bogdan. 2016. "Puppet States: A Growing Trend of Covert Occupation." In Yearbook of International Humanitarian Law 2015, edited by Terry D. Gill, 43-65. The Hague: Asser Press and Springer.

Jourde, Cédric. 2007. "The International Relations of Small Neoauthoritarian States: Islamism, Warlordism, and the Framing of Stability." International Studies Quarterly 51 (2): 481-503.

Kanet, Roger E., and Matthew Sussex, eds. 2015. Power, Politics and Confrontation in Eurasia: Foreign Policy in a Contested Region. London: Palgrave Macmillan. 
Karaban, Dmitrii. 2017. "Kak zhivut v Moldove i Pridnestrovie [Life in Moldova and Transnistria].” 2000, October 11. https://www.2000.ua/v-nomere/derzhava/realii/kakzhivut-v-moldove-i-pridnestrove.htm.

Kennedy, Ryan. 2016. "The limits of soft balancing: The frozen conflict in Transnistria and the challenge to EU and NATO strategy." Small Wars \& Insurgencies 27 (3): 512-537.

Kim, Sunhyuk, and Wonhyuk Lim. 2007. "How to Deal with South Korea." The Washington Quarterly 30 (2): 71-82.

Kolstø, Pål. 2006. "The Sustainability and Future of Unrecognized Quasi-States.” Journal of Peace Research 43 (6): 723-740.

Kolstø, Pål, and Helge Blakkisrud. 2017. "Regime Development and Patron-Client Relations: The 2016 Transnistrian Presidential Elections and the 'Russia Factor'." Demokratizatsiya 25 (4): 503-528.

Konończuk, Wojciech, and Witold Rodkiewicz. 2012. "Could Transnistria block Moldova's integration with the EU?" OSW Commentary, October 23.

https://www.osw.waw.pl/sites/default/files/commentary_95.pdf.

MID PMR. 2012. "Kontseptsiya vneshnei politiki Pridnestrovskoi Moldavskoi Respubliki [Conception of external policy of the Transnistrian Moldovan Republic]." Ministerstvo innostrannykh del Pridnestrovskoi Moldavskoi Respubliki, November 20. http://mfapmr.org/ru/Qpj.

Kosienkowski, Marcin. 2012. Continuity and Change in Transnistria's Foreign Policy after the 2011 Presidential Elections. Lublin: The Catholic University of Lublin Publishing House.

Krasnoselskii, Vadim. 2018a. "Pridnestrovie mozhet byt priznano kak Kosovo [Transnistria can be recognized as Kosovo]." Interview with Nezavisimaya Gazeta, January 22. http://www.ng.ru/cis/2018-01-22/1_7155_pridnestrovie.html.

Krasnoselskii, Vadim. 2018b. "Pridnestrovie - sostavnaya chast Russkogo mira: Tekushchaya situatsiya i perspektivy razvitiya [Transnistria - an integral part of the Russian world: current situation and prospects for development]." Lecture, Mezhdunarodnyi forum rossiiskikh sootechestvennikov 'Vmeste s Rossiei', Moscow, March 5. https://bit.ly/2Nj7fQf.

Krasnoselskii, Vadim. 2018c. "Poka rossiiskii mirotvorets na Dnestre — voiny ne budet [As long as the Russian peacekeeper is on the Dniester - there will be no war]." Interview with Izvestiya, July 30. https://iz.ru/771442/aleksei-zabrodin-dmitrii-laru/poka-rossiiskiimirotvoretc-na-dnestre-voiny-ne-budet.

Krudu, Igor. 2018. "Defitsit byudzheta Pridnestrovya v sleduyushchem godu sostavit 1,8 milliarda rublei [The budget deficit of Transnistria will amount to 1.8 billion rubles next year]." Komsomolskaya Pravda, September 22. https://www.kp.md/online/news/3243863/. 
Ladwig, Walter C. 2016. "Influencing Clients in Counterinsurgency: U.S. Involvement in El Salvador's Civil War, 1979-92.” International Security 41 (1): 99-146.

Lynch, Dov. 2004. Engaging Eurasia's Separatist States: Unresolved Conflicts and De Facto States. Washington, DC: United States Institute of Peace Press.

MID PMR. 2009. "MID Pridnestrovya napravil soboleznovaniya MIDu Yuzhnoi Osetii [Foreign Ministry of Transnistria sent condolences to the Foreign Ministry of South Ossetia]." Ministerstvo inostrannykh del Pridnestrovskoi Moldavskoi Respubliki, August 7. http://mfa-pmr.org/ru/Lxt.

MID PMR. 2014. “Zayavlenie Ministerstva inostrannykh del PMR v svyazi s prinyatiem Kryma i Sevastopolya v sostav Rossiiskoi Federatsii [Statement of the Ministry of Foreign Affairs of Transnistria in connection with the accession of the Crimea and Sevastopol into the Russian Federation]." Ministerstvo inostrannykh del Pridnestrovskoi Moldavskoi Respubliki, March 19. http://mfa-pmr.org/ru/pnh.

MID RF. 2016. “O vstreche stats-sekretarya - zamestitelya Ministra inostrannykh del Rossii G. B. Karasina s Prezidentom Pridnestrovya V. N. Krasnoselskim [On the meeting of Secretary of State - Deputy Minister of Foreign Affairs of Russia Grigory Karasin with President of Transnistria V. N. Krasnoselskii]." Ministerstvo inostrannykh del Rossiiskoi Federatsii, December 20. http://www.mid.ru/foreign_policy/news//asset_publisher/cKNonkJE02Bw/content/id/2574860.

MID RF. 2018. "Vystuplenie postoyannogo predstavitelya Rossii pri OBSE A. K.

Lukashevicha na Zasedanii postoyannogo soveta OBSE v otvet na doklad glavy Missii OBSE v Moldavii, Vena, 12 iyulya 2018 goda [Speech by Alexander Lukashevich, Permanent Representative of Russia to the OSCE, at a meeting of the OSCE Permanent Council in response to the report of the Head of the OSCE Mission to Moldova, Vienna, July 12, 2018]." Ministerstvo inostrannykh del Rossiiskoi Federatsii, July 13. http://www.mid.ru/foreign_policy/news//asset_publisher/cKNonkJE02Bw/content/id/3294212.

MZS Ukrayiny. 2014. "Bryfinh v MZS [Briefing in the Ministry of Foreign Affairs]." Ministerstvo Zakordonnykh Sprav Ukrayiny, March 20. https://mfa.gov.ua/ua/presscenter/briefing/1197-brifing-v-mzs.

Nagashima, Toru. 2017. "Russia's Passportization Policy towards Unrecognized Republics: Abkhazia, South Ossetia, and Transnistria." Problems of Post-Communism 12 (4): 1-14.

Novosti Pridnestrovya. 2014. "Yevgenii Shevchuk: 'Pridnestrovie za vsyu svoyu istoriyu nikogda ni na kogo ne napadalo' [Yevgenii Shevchuk: 'Transnistria has never attacked any other country']." Novosti Pridnestrovya, March 11. https://novostipmr.com/ru/news/14-0311/evgeniy-shevchuk-pridnestrove-za-vsyu-svoyu-istoriyu-nikogda-ni-na.

O’Loughlin, John, Gerard Toal, and Rebecca Chamberlain-Creangă. 2013. "Divided space, divided attitudes? Comparing the Republics of Moldova and Pridnestrovie (Transnistria) using simultaneous surveys." Eurasian Geography and Economics 54 (2): 227-258. 
Oleksy, Piotr. 2014. “Transnistria’s Difficult Choice.” New Eastern Europe, August 5. http://neweasterneurope.eu/old_site/articles-and-commentary/1286-transnistria-s-difficultchoice.

Oleksy, Piotr. 2016. Wspólnota z przypadku: Studium tożsamości mieszkańców Naddniestrza [Community by Chance: Study of the Identity of the Inhabitants of Transnistria]. Gniezno: Instytut Kultury Europejskiej UAM w Gnieźnie.

Popescu, Nicu. 2006. “'Outsourcing' de facto Statehood: Russia and the Secessionist Entities in Georgia and Moldova." CEPS Policy Brief 109.

https://www.ceps.eu/system/files/book/1361.pdf.

Ravenhill, John. 1985. Collective Clientelism: The Lomé Conventions and North-South Relations. New York: Columbia University Press.

Regnum. 2009. "Rossiiskii deputat: Rossiya gotova zashchishchat svoikh sootechestvennikov v Pridnestrovie [Russian MP: Russia is ready to defend its compatriots in Transnistria]." Regnum, August 31. https://regnum.ru/news/polit/1201278.html.

Regnum. 2015. "Tiraspol: Agressiya v otnoshenii PMR budet oznachat napadenie na Rossiyu [Tiraspol: Aggression against Transnistria will mean an attack on Russia].” Regnum, July 27. https://regnum.ru/news/1946454.html.

Robertson, Dylan C. 2014. "Is Transnistria the ghost of Crimea's future?" The Christian Science Monitor, March 5. https://www.csmonitor.com/World/Europe/2014/0305/IsTransnistria-the-ghost-of-Crimea-s-future.

Rodkiewicz, Witold. 2012. "Russia's strategy towards Moldova: Continuation or change?" OSW Commentary, April 19. https://www.osw.waw.pl/sites/default/files/commentary_74.pdf.

Rogstad, Adrian. 2016. “The Next Crimea? Getting Russia's Transnistria Policy Right.” Problems of Post-Communism 65 (1): 49-64.

Rossiiskaya Gazeta. 2018. "Rogozin: RF ne svernet mirotvorcheskuyu missiyu v Pridnestrovie [Rogozin: Russia will not end the peacekeeping mission in Transnistria]." April 13. https://rg.ru/2018/04/13/rogozin-rf-ne-svernet-mirotvorcheskuiu-missiiu-vpridnestrove.html.

Secrieru, Stanislav. 2016. "Transnistria Zig-zagging towards a DCFTA." PISM Policy Paper 145 (4). https://www.pism.pl/files/?id_plik=21295.

Shoemaker, Christopher C., and John W. Spanier. 1984. Patron-Client State Relationships: Multilateral Crises in the Nuclear Age. New York: Praeger.

Smirnov, Igor. 2007. Vmeste s Rossiei [Together with Russia]. Tiraspol: TIPAR.

Soloviev, Vladimir. 2007. "Ruka Moskvy davat ustala: Lider Pridnestrovya zloupotrebil rossiiskoi pomoshchyu [Moscow hand ceased contributing: Transnistrian leader abused Russian help]." Kommersant, April 6. https://www.kommersant.ru/doc/756473. 
Soloviev, Vladimir. 2008. "Pridnestrovie smirilos s Moldaviei: Rossiya vynudila Igorya Smirnova k peregovoram s Kishinevom [Transnistria reconciled with Moldova. Russia forced Igor Smirnov to negotiate with Chisinau]." Kommersant, February 29. https://www.kommersant.ru/doc/858155.

Soloviev, Vladimir, and Dmitrii Butrin. 2010. "Ruka Moskvy davat ustala: Rossiya zamorozila finansovuyu pomoshch Pridnestrovyu [Moscow hand ceased to contribute: Russia froze financial assistance to Transnistria]." Kommersant, July 23. https://www.kommersant.ru/doc/1473776.

Sorokin, Gerald L. 1997. "Patrons, clients, and allies in the Arab-Israeli conflict." Journal of Strategic Studies 20 (1): 46-71.

Sputnik. 2016. "Krasnoselskii: Ekonomika Pridnestrovya zhiva blagodarya Rossii [Krasnoselskii: Transnistrian Economy lives thanks to Russia].” Sputnik, December 21. https://ru.sputnik.md/news/20161221/10445026/krasnoselskijj-ekonomika-pridnestrovjerossia.html.

Tètreault, Mary Ann. 1991. "Autonomy, necessity, and the small state: Ruling Kuwait in the twentieth century." International Organization 45 (4): 565-91.

Tkhorik, Vladimir, Mariya Tuzlova, and Natalya Zvarish. 2017. "Kontrabandnaya 'gumanitarka' dlya Pridnestrovya [Contraband "humanitarian aid" for Transnistria]." RISE Moldova, June 29. https://www.rise.md/rusa/контрабандная-гуманитарка-для-при/.

Toal, Gerard. 2017. Near abroad: Putin, the West and the contest over Ukraine and the Caucasus. New York: Oxford University Press.

Ukrinform. 2014. "SBU zatrymala shpyhuna z prydnistrovskoho KDB [Ukrainian Intelligence Service arrested a spy from Transnistrian intelligence office]." Ukrinform, March 31. https://www.ukrinform.ua/rubric-polytics/1640800sbu_zatrimala_shpiguna_z_pridnistrovskogo_kdb_1923733.html.

Veenendaal, Wouter P. 2017. "Analyzing the Foreign Policy of Microstates: The Relevance of the International Patron-Client Model.” Foreign Policy Analysis 13 (3): 561-577. 